\title{
PENERAPAN MODEL PEMBELAJARAN THINK PAIR SHARE DAN MEDIA UIDEO DAKWAH UNTUK MENINGKATKAN KETERAMPILAN MENULIS PARAgRAF persuasIF BERMUATAN PENDIDIKAN KARAKTER pada siswa Kelas X ma
}

\author{
RIANA HASTITI ${ }^{1)}$, EVI CHAMALAH ${ }^{2),}$ LELI NISFI SETIANA $^{3)}$ \\ Prodi PBSI, FKIP Universitas Islam Sultan Agung \\ chamalah@unissula.ac.id², lelinisfisetiana@yahoo.co.id ${ }^{3}$
}

Pertama Diterima: 27 April 2017

Bukti Akhir Diterima: 06 Mei 2017

\begin{abstract}
Abstrak
Tujuan penelitian ini adalah (1) mendeskripsikan peningkatan keterampilan menulis paragraf persuasif siswa kelas X MA Al Anwar Mranggen Demak setelah diterapkan model Think Pair Share dan media video dakwah bermuatan pendidikan karakter, (2) mendeskripsikan peningkatan sikap belajar siswa kelas X MA Al Anwar Mranggen Demak setelah mengikuti pembelajaran menulis paragraf persuasif dengan model Think Pair Share dan media video dakwah bermuatan pendidikan karakter, dan (3) mendiskripsikan peningkatan motivasi belajar siswa kelas X MA Al Anwar Mranggen Demak setelah mengikuti pembelajaran menulis paragraf persuasif dengan model Think Pair Share dan media video dakwah bermuatan pendidikan karakter. Penelitian ini merupakan penelitian kuantitatif dan kualitatif. Penelitian kuantitatif yaitu berupa analisis nilai dari hasil tes menulis paragraf persuasif. Penelitian kualitatif berupa analisis data dari hasil nontes melalui observasi, angket, wawancara, dan dokumentasi. Berdasarkan hasil penelitian yang telah dilakukan, maka dapat diketahui bahwa keterampilan siswa kelas X MA Al Anwar Mranggen Demak dalam menulis paragraf persuasif mengalami peningkatan. Hal tersebut dapat diketahui melalui hasil menulis paragraf persuasif disetiap siklusnya. Pada prasiklus siswa memperoleh nilai rata-rata kelas sebesar 43,5. Pada siklus I nilai rata-rata kelas siswa meningkat menjadi 61,17. Pada siklus II siswa memperoleh nilai rata-rata kelas sebesar 64,83 dan pada siklus III nilai rata-rata kelas siswa menjadi 78. Hal tersebut membuktikan bahwa hasil menulis paragraf persuasif siswa mengalami peningkatan pada siklus I, siklus II, dan siklus III.
\end{abstract}

Kata Kunci: Menulis Paragraf Persuasif, Media Video Dakwah, Model Think Pair Share, Pendidikan Karakter.

\begin{abstract}
The purpose of this research is (1) to describe the improvement of writing skill of persuasive writing of class X student of MA Al Anwar Mranggen Demak after applied Think Pair Share model and video media of da'wah with character education, (2) to describe the improvement of learning attitude of grade X MA Al Anwar Mranggen Demak after following the writing of persuasive paragraph with Think Pair Share model and video media da'wah with character education, and (3) to describe the increase of learning motivation of grade X MA Al Anwar Mranggen Demak after following lesson writing persuasive paragraph with Think Pair Share model and video media of da'wah Charged character education. This research is a quantitative and qualitative research. Quantitative research that is in
\end{abstract}


the form of value analysis from test result writing persuasive paragraph. Qualitative research in the form of data analysis from nontes result through observation, questionnaire, interview, and documentation. Based on the result of research that has been done, it can be seen that the skills of students of class X MA Al Anwar Mranggen Demak in writing persuasive paragraphs have increased. This can be known through the writing of a persuasive paragraph in each cycle. In prasiklus students get a grade point average of 43,5. In the first cycle the average grade of the students increased to 61,17. In cycle II the students get the average grade of 64,83 and on the third cycle the average grade of the students to 78. It proves that the writing of the persuasive paragraph of the students has increased in cycle I, cycle II, and cycle III.

Key words: Writing Persuasive Paragraph, Media Video Dakwah, Think Pair Share Model, Character Education.

\section{PENDAHULUAN}

Menulis merupakan sebuah proses kreatif dimana kita dapat menuangkan gagasan dalam bentuk bahasa tulis dalam tujuan, misalnya memberitahu, meyakinkan, atau menghibur. Hasil dari proses kreatif ini biasa disebut dengan istilah karangan atau tulisan. Kedua tulisan tersebut mengacu pada hasil yang sama meskipun ada pendapat yang mengatakan kedua istilah tersebut memiliki pengertian yang berbeda.

Kegiatan menulis merupakan bagian yang tidak terpisahkan dalam seluruh proses belajar yang dialami oleh siswa. Tujuan dari pembelajaran menulis itu sendiri yaitu agar siswa mampu mengungkapkan ide, gagasan, pendapat, dan pengetahuan secara tertulis. Dengan keterampilan menulis yang dimiliki, siswa nantinya dapat mengembangkan kreativitas dan menggunakan bahasa untuk menyalurkan kreativitasnya dalam kehidupan sehari-hari.

Menulis itu merupakan suatu kegiatan yang tidak mudah dilakukan oleh siswa meskipun disetiap jenjang pendidikan selalu diajarkan tentang menulis. Tarigan (dalam Rovimiyanti, 2009) mengatakan bahwa menulis merupakan suatu representasi bagian dari kesatuan-kesatuan ekspresi bahasa. Menulis juga merupakan kegiatan menurunkan atau melukiskan lambang-lambang grafik yang menggambarkan suatu bahasa yang dipahami oleh seseorang, sehingga lambang-lambang grafik tersebut dapat dibaca dan dipahami. Menulis dipandang sebagai salah satu aspek penting dalam proses komunikasi.

Berdasarkan pengertian di atas dapat disimpulkan bahwa menulis merupakan suatu kegiatan yang tidak terpisahkan selama belajar di bangku sekolah. Menulis adalah kegiatan yang tidak mudah dilakukan oleh siswa karena membutuhkan waktu, ketelitian, dan kreativitas untuk bisa menghasilkan sebuah tulisan yang dapat dimengerti oleh pembaca. Selain itu menulis adalah salah satu aspek penting dalam suatu pembelajaran. 
Pembelajaran keterampilan menulis memiliki berbagai bentuk, salah satunya adalah keterampilan menulis karangan. Dalam pembelajaran menulis diharapkan siswa tidak hanya dapat mengembangkan kemampuan membuat karangan namun juga diperlukan kecermatan untuk menuangkan ide atau gagasan dengan cara membuat karangan yang menarik untuk dibaca. Diantaranya siswa harus dapat menyusun dan menghubungkan antara kalimat yang satu dengan kalimat yang lain sehingga menjadi karangan yang utuh dan mudah dipahami oleh pembaca.

Mata pelajaran Bahasa Indonesia dalam Kurikulum Tingkat Satuan Pendidikan (KTSP) mengedepankan pada penguasaan pengetahuan, keterampilan berbahasa dan sikap positif terhadap bahasa dan sastra Indonesia. Pelajaran menulis dalam KTSP sendiri dijabarkan dalam dua aspek yaitu aspek sastra dan aspek nonsastra. Aspek sastra contohnya menulis pantun, menulis puisi, menulis cerpen, menulis drama, dan masih banyak yang lainnya. Adapun pada aspek nonsastra contohnya menulis proposal, menulis karya ilmiah, menulis catatan kaki, menulis teks pidato, menulis paragraf, dan masih banyak yang lainnya. Aspek sastra dan nonsastra, termasuk pembelajaran keterampilan menulis yang ada di SMA kelas X baik semester I maupun semester II. Aspek nonsastra yang terdapat pada pembelajaran menulis untuk kelas $\mathrm{X}$ terutama pada standar kompetensi mengungkapkan informasi melalui penulisan paragraf dan teks pidato dan kompetensi dasar menulis gagasan untuk meyakinkan atau mengajak pembaca bersikap atau melakukan sesuatu dalam bentuk paragraf persuasif. Melalui pembelajaran keterampilan tersebut peserta didik diharapkan mampu menulis paragraf persuasi dan menghasilkan karya yang baik.

Paragraf persuasi adalah paragraf yang bertujuan untuk mempengaruhi emosionalitas pembaca. Paragraf ini juga membutuhkan data dan contoh-contoh konkret untuk mempengaruhi pembaca (Kokasih, 2012, hal 21). Hal tersebut mengindikasikan bahwa sebuah tulisan persuasi akan mampu mengajak pendengar atau pembaca mengikuti kehendak penulis. Dengan demikian peserta didik dituntut untuk memiliki kemampuan mengolah informasi agar menjadi paragraf persuasi yang menarik. Jadi, paragraf persuasi adalah suatu paragraf yang bertujuan untuk membujuk pembaca untuk melakukan sesuatu. Sebuah paragraf persuasif juga harus didukung dengan data-data yang konkret agar dapat meyakinkan pembaca dan pembaca mau melakukan atau bertindak sesuatu setelah membaca paragraf persuasif tersebut.

Berdasarkan hasil wawancara yang dilakukan oleh peneliti dengan guru Bahasa Indonesia di MA Al Anwar Mranggen Demak diketahui bahwa pada saat proses pembelajaran menulis paragraf persuasif masih banyak siswa yang mengalami kesulitan, 
terutama dalam hal menentukan ide dan merangkai kata-kata. Hal ini terjadi karena siswa tidak mengetahui tujuan dan manfaat dari pembelajaran menulis paragraf persuasif, selain itu siswa kurang berantusias dalam pembelajaran menulis karena mereka merasa kalau pembelajaran menulis itu adalah kegiatan yang sulit dan membosankan.

Penggunaan metode dan media yang diterapkan pendidik dalam pembelajaran menulispun masih belum efektif.Selama ini metode yang digunakan masih berupa metode ceramah dan tidak menggunakan media pembelajaran saat kegiatan belajar mengajar berlangsung. Guru menggunakan media hanya pada materi-materi tertentu saja, misalnya menonton drama.

Guru adalah sebagai perencana, pelaksana, dan pengembang kurikulum bagi kelasnya. Oleh karena itu semua yang diterapkan guru di dalam kelas akan berpengaruh pada motivasi belajar siswa yang merupakan salah satu faktor yang mempengaruhi keberhasilan belajar dan proses pembelajaran itu sendiri. Kegiatan menulis siswa dapat ditingkatkan jika guru menggunakan media sebagai contoh dalam pembelajaran, penggunaan media pembelajaran akan sangat membantu keefektifan proses pembelajaran dan penyampaian pesan serta isi pelajaran.

Banyak cara yang bisa digunakan oleh pendidik untuk meningkatkan keterampilan menulis paragraf persuasi siswa. Salah satunya yaitu dengan adanya inovasi dalam proses pembelajaran, misalnya seperti menerapkan model pembelajaran inovatif untuk siswa dan menggunakan media yang dapat menarik perhatian siswa. Dalam penelitian ini peneliti akan berinovasi dalam penggunaan model pembelajaran dan media pembelajaran yang mungkin belum diterapkan dalam proses pembelajaran sebelumnya.

Model pembelajaran yang akan digunakan dalam penelitian ini yaitu model pembelajaran Think Pair Share, dimana model pembelajaran ini nantinya akan menjadikan proses pembelajaran yang menuntut kerja sama siswa antar sesama kelompok atau pasangannya. Jadi dalam model ini nantinya siswa diberi tugas untuk menulis paragraf persuasif oleh guru, dan siswa diminta untuk berpikir bersama pasangannya, kemudian siswa menulis paragraf persuasif. Setelah selesai menulis setiap pasangan membacakan hasil tulisannya kepada teman-teman yang lain. Model pembelajaran ini tentunya akan membuat siswa memiliki rasa sosial dan pemikiran yang kreatif.

Selain model pembelajaran, peneliti juga akan menggunakan media pembelajaran yaitu media video dakwah. Media ini nantinya akan digunakan sebagai tema dalam menulis paragraf persuasif siswa. Dengan media ini akan memudahkan siswa dalam memilih tema dan mengembangkannya menjadi sebuah kata-kata. 
Pendidikan karakter menurut Megawangi (dalam Kesuma 2013, hal 5) merupakan sebuah usaha untuk mendidik anak-anak agar dapat mengambil keputusan dengan bijak dan mempraktikkannya dalam kehidupan sehari-hari. Jadi pendidikan karakter yaitu pembelajaran yang mengarah pada pengembangan perilaku anak secara utuh yang didasarkan pada suatu nilai tertentu yang dirujuk oleh sekolah.Dalam penelitian ini nantinya siswa diharapkan pada saat pembelajaran di sekolah agar dapat menanamkan pendidikan karakter seperti jujur, gotong-royong, tanggung jawab, disiplin, dan lain sebagainya.

Berdasarkan latar belakang tersebut peneliti akan melakukan penelitian dengan judul "Penerapan Model Pembelajaran Think Pair Share dan Media Video Dakwah untuk Meningkatkan Keterampilan Menulis Paragraf Persuasif Bermuatan Pendidikan Karakter Pada Siswa Kelas X MA”.

\section{METODE PENELITIAN}

\section{Desain Penelitian}

Penelitian ini dilakukan melalui empat siklus, yaitu dimulai dari prasiklus, siklus I, siklus II, dan siklus III. Tiap siklus terdiri atas empat tahapan, yaitu perencanaan, tindakan, pengamatan, dan refleksi. Prasiklus bertujuan untuk mengetahui kemampuan siswa dalam menulis paragraf persuasif. Prasiklus digunakan sebagai refleksi untuk melaksanakan siklus I. Hasil proses tindakan siklus I digunakan sebagai refleksi untuk melaksanakan siklus II. Hasil dari tindakan siklus II digunakan untuk mengetahui peningkatan keterampilan menulis paragraf persuasif di kelas berdasarkan refleksi siklus I. Tindakan siklus III bertujuan untuk mengetahui perubahan atau peningkatan keterampilan menulis paragraf persuasif setelah adanya refleksi dari siklus I dan siklus II, dan jika pada siklus II belum ada peningkatan.

\section{Tempat dan Waktu Penelitian}

Penelitian ini dilaksanakan di MA Al Anwar Mranggen Demak. Penelitian ini dilaksanakan pada tahun 2017.

\section{Subjek dan Objek Penelitian}

Subjek dalam penelitian ini adalah siswa kelas X MA Al Anwar Mranggen Demak yang berjumlah 30 siswa. Subjek yang dipilih merupakan pertimbangan peneliti terhadap pemberlakuan karakter-karakter Islami yang diterapkan di MA Al Anwar Mranggen Demak.

Objek penelitian dalam penelitian ini yaitu penerapan model Think Pair Share dan media video dakwah dalam pembelajaran keterampilan menulis paragraf persuasif. 


\section{Populasi dan Sampel}

Menurut Sugiyono (2009, hal 80) populasi adalah wilayah generalisasi yang terdiri atas objek atau subjek yang mempunyai kualitas dan karakteristik tertentu yang ditetapkan oleh peneliti untuk dipelajari dan kemudian ditarik kesimpulannya. Dari pengertian tersebut maka populasi pada penelitian ini yaitu MA Al Anwar Mranggen Demak, sedangkan sampel yang digunakan dari populasi yaitu siswa kelas X MA Al Anwar Mranggen Demak.

\section{Variabel Penelitian}

Variabel penelitian adalah suatu atribut atau sifat atau nilai dari orang, objek atau kegiatan yang mempunyai variasi tertentu yang ditetapkan oleh peneliti untuk dipelajari dan kemudian ditarik kesimpulannya (Sugiyono 2015, hal 61). Penelitian ini menggunakan empat variabel yaitu, 1) Keterampilan menulis paragraf persuasif, 2) model pembelajaran Think Pair Share, 3) media video dakwah, dan 4) bermuatan pendidikan karakter.

\section{Instrumen Penelitian}

Instrumen penelitian merupakan alat bantu yang digunakan oleh peneliti untuk mengumpulkan data penelitian dengan cara melakukan pengukuran (Widoyoko 2016, hal 51). Instrumen yang peneliti gunakan dalam penelitian ini yaitu instrumen tes dan instrumen nontes.

\section{Teknik Pengumpulan Data}

Teknik pengumpulan data yang digunakan dalam penelitian ini adalah teknik tes dan nontes. Teknik pengumpulan data tes digunakan untuk mengetahui kemampuan siswa dalam menulis paragraf persuasif setelah dilakukan pembelajaran dengan model think pair share dan media video dakwah. Teknik nontes digunakan untuk mengetahui respon siswa terhadap pembelajaran dengan model think pair share dan media video dakwah. Teknik yang digunakan berupa teknik observasi, wawancara, angket, dan dokumentasi.

\section{Teknik Analisis Data}

Teknik analisis data merupakan cara yang digunakan peneliti dalam mengolah data yang telah diperoleh berdasarkan penelitian yang sudah dilakukan. Teknik analisis data yang digunakan dalam penelitian ini yaitu dilakukan dengan teknik deskripsif kuantitatif dan kualitatif. 


\section{HASIL PENELITIAN DAN PEMBAHASAN}

\section{Peningkatan Keterampilan Menulis Paragraf Persuasif}

Berdasarkan hasil tes menulis paragraf persuasif dengan model think pair share dan media video dakwah bermuatan pendidikan karakter diperoleh hasil bahwa nilai rata-rata siswa kelas X MA AL Anwar Mranggen Demak mengalami peningkatan dari 61,17 pada siklus I menjadi 64,83 pada siklus II dan meningkat lagi menjadi 78 pada siklus III, sehingga mengalami peningkatan 3,66 dari siklus I ke siklus II dan 13,17 dari siklus II ke siklus III.

Pembahasan hasil penelitian ini berdasarkan pada hasil prasiklus, hasil tindakan siklus I, hasil tindakan siklus II, dan hasil tindakan siklus III. Pembahasan hasil penelitian ini meliputi hasil tes dan hasil nontes prasiklus, siklus I, siklus II, dan siklus III. Pembahasan hasil tes berpedoman pada perolehan skor yang dicapai siswa dalam tes menulis paragraf persuasif. Aspek-aspek penilaian terdiri dari lima aspek yaitu, 1) aspek kesesuaian isi dengan tema, 2) aspek pilihan kata, 3) aspek ejaan dan tanda baca, 4) aspek keefektifan kalimat, dan 5) aspek ketepatan jenis paragraf. Dari hasil kelima aspek tersebut diakumulasikan menjadi satu untuk mendapatkan hasil tes menulis paragraf persuasif pada prasiklus, siklus I, siklus II, dan siklus III. Berikut akan dipaparkan tabel perbandingan hasil tes menulis paragraf persuasif siswa dari prasiklus, siklus I, siklus II, dan siklus III.

Tabel 1 Perbandingan Hasil Menulis Paragraf Persuasif

Prasiklus, Siklus I, Siklus II, dan Siklus III.

\begin{tabular}{|c|l|c|c|c|c|}
\hline \multirow{2}{*}{ No } & \multirow{2}{*}{ Aspek } & \multicolumn{4}{c|}{ Rata-rata } \\
\cline { 3 - 6 } & & PRA & S I & S II & S III \\
\hline 1 & Kesesuaian isi dengan tema & 7,83 & 14,83 & 15 & 19,5 \\
\hline 2 & Pilihan kata & 6,5 & 7,5 & 8,33 & 10,33 \\
\hline 3 & Ejaan dan tanda baca & 6,83 & 7,83 & 8,33 & 8,2 \\
\hline 4 & Keefektifan kalimat & 10,5 & 12,33 & 13,67 & 17,67 \\
\hline 5 & Ketepatan jenis paragraph & 11,5 & 18,67 & 19,5 & 22,33 \\
\hline \multicolumn{2}{|c|}{ Nilai Akhir } & $\mathbf{4 3 , 5}$ & $\mathbf{6 1 , 1 7}$ & $\mathbf{6 4 , 8 3}$ & $\mathbf{7 8}$ \\
\hline
\end{tabular}

Berdasarkan tabel 1 hasil tes peningkatan keterampilan menulis paragraf persuasif dari prasiklus, siklus I, siklus II, dan siklus III dapat dijelaskan bahwa keterampilan menulis paragraf persuasif pada setiap aspek penilaian mengalami peningkatan.

Hasil tes menulis paragraf persuasif pada prasiklus mendapatkan nilai rata-rata 43,5 dengan kategori kurang pada rentang nilai 0-59. Nilai tersebut diperoleh dari beberapa aspek 
penilaian yang terdiri dari lima aspek, yaitu 1) aspek kesesuaian isi dengan tema, 2) aspek pilihan kata, 3) aspek ejaan dan tanda baca, 4) aspek keefektifan kalimat, dan 5) aspek ketepatan jenis paragraf. Aspek kesesuaian isi dengan tema memperoleh nilai rata-rata 7,83 dengan kategori kurang. Aspek pilihan kata memperoleh nilai rata-rata 6,5 dengan kategori cukup baik. Aspek ejaan dan tanda baca memperoleh nilai rata-rata 6,83 dengan kategori cukup baik. Aspek keefektifan kalimat memperoleh nilai rata-rata 10,5 dengan kategori kurang. Selanjutnya, aspek ketepatan jenis paragraf memperoleh nilai rata-rata 11,5 dengan kategori kurang.

Hasil tes menulis paragraf persuasif pada siklus I memperoleh nilai rata-rata 61,17 dengan kategori cukup baik pada rentang nilai 60-74, nilai tersebut diperoleh dari beberapa aspek penilaian. Aspek kesesuaian isi dengan tema memperoleh nilai rata-rata 14,83 dengan kategori cukup baik. Aspek pilihan kata memperoleh nilai rata-rata 7,5 dengan kategori cukup baik. Aspek ejaan dan tanda baca memperoleh nilai rata-rata 7,83 dengan kategori cukup baik. Aspek keefektifan kalimat memperoleh nilai rata-rata 12,33 dengan kategori kurang dan aspek ketepatan jenis paragraf memperoleh nilai rata-rata 18,67 dengan kategori cukup baik. Dengan demikian dapat diketahui peningkatan hasil tes menulis paragraf persuasif dari prasiklus ke siklus I mencapai $17,67 \%$.

Hasil tes menulis paragraf persuasif pada siklus II mendapatkan nilai rata-rata 64,83 dengan kategori cukup baik pada rentang nilai 60-74. Aspek kesesuaian isi dengan tema memperoleh nilai rata-rata 15 dengan kategori baik. Aspek pilihan kata memperoleh nilai rata-rata 7,5 dengan kategori cukup baik. Aspek ejaan dan tanda baca memperoleh nilai ratarata 7,83 dengan kategori cukup baik. Aspek keefektifan kalimat memperoleh nilai 13,67 dengan kategori cukup baik dan aspek ketepatan jenis paragraf memperoleh nilai 19,5 dengan kategori cukup baik. Dengan demikian dapat diketahui peningkatan hasil tes menulis paragraf persuasif dari siklus I ke siklus II mencapai 3,66\%.

Hasil tes menulis paragraf persuasif siklus III mendapatkan nilai rata-rata 78 dengan kategori baik pada rentang nilai 75-84. Aspek kesesuaian isi dengan tema memperoleh nilai rata-rata 19,5 dengan kategori baik. Aspek pilihan kata memperoleh nilai rata-rata 10,33 dengan kategori baik. Aspek ejaan dan tanda baca memperoleh nilai rata-rata 8,2 dengan kategori cukup baik. Aspek keefektifan kalimat memperoleh nilai rata-rata 17,67 dengan kategori cukup baik dan aspek ketepatan jenis kalimat memperoleh nilai rata-rata 22,33 dengan kategori baik. Dengan demikian dapat diketahui peningkatan hasil tes menulis paragraf persuasif dari siklus II ke siklus III mencapai 13,17\%. 
Peningkatan nilai rata-rata tiap aspek pada prasiklus, siklus I, siklus II, dan siklus III membuktikan bahwa penerapan model think pair share dan media video dakwah bermuatan pendidikan karakter dapat meningkatkan keterampilan siswa menulis paragraf persuasif siswa kelas X MA AL Anwar Mranggen Demak. Dengan demikian dapat disimpulkan bahwa melalui model pembelajaran think pair share dan media video dakwah bermuatan pendidikan karakter dapat menjadikan siswa tertarik terhadap pembelajaran dan memotivasi siswa dalam pembelajaran menulis, khususnya keterampilan menulis paragraf persuasif.

\section{Peningkatan Sikap Belajar Siswa}

Setelah penelitian dilakukan, peningkatan tidak hanya terjadi pada hasil tes menulis paragraf persuasif saja, melainkan juga terjadi peningkatan sikap belajar siswa setelah dilakukan pembelajaran dengan model think pair share dan media video dakwah bermuatan pendidikan karakter. Hal ini dapat diketahui dari perbandingan hasil instrumen nontes prasiklus, siklus I, siklus II, dan siklus III, yang meliputi observasi atau pengamatan, angket atau kuesioner, wawancara dan dokumentasi.

\section{Peningkatan Sikap Belajar Siswa Berdasarkan Hasil Observasi}

Observasi sikap belajar siswa digunakan peneliti untuk menilai peningkatan sikap belajar siswa saat proses pembelajaran berlangsung dari prasiklus sampai siklus III. Perbandingan dari hasil observasi setelah dilakukan pembelajaran dari prasiklus sampai siklus III dapat dilihat pada tabel berikut.

Tabel 2 Perbandingan Hasil Observasi Sikap Belajar Siswa

Prasiklus, Siklus I, siklus II, dan siklus III

\begin{tabular}{|c|c|c|c|c|c|c|c|c|c|}
\hline \multirow{2}{*}{ No } & \multirow{2}{*}{ Rentang nilai } & \multicolumn{2}{|c|}{ Prasiklus } & \multicolumn{2}{|c|}{ Siklus I } & \multicolumn{2}{|c|}{ Siklus II } & \multicolumn{2}{|c|}{ Siklus III } \\
\hline & & $\mathbf{F}$ & $\%$ & $\mathbf{F}$ & $\%$ & $\mathbf{F}$ & $\%$ & $\mathbf{F}$ & $\%$ \\
\hline 1 & $85-100$ & 0 & 0 & 5 & 16,67 & 13 & 43,33 & 21 & 70 \\
\hline 2 & $75-84$ & 0 & 0 & 3 & 10 & 7 & 23,33 & 6 & 20 \\
\hline 3 & $60-74$ & 2 & 6,67 & 21 & 70 & 10 & 33,33 & 3 & 10 \\
\hline 4 & $0-59$ & 28 & 93,33 & 1 & 3,33 & 0 & 0 & 0 & 0 \\
\hline & Jumlah & 30 & 100 & 30 & 100 & 30 & 100 & 30 & 100 \\
\hline & Rata-rata & \multicolumn{2}{|c|}{46,83} & \multicolumn{2}{|c|}{68,5} & \multicolumn{2}{|c|}{78,67} & \multicolumn{2}{|c|}{85,83} \\
\hline
\end{tabular}


Berdasarkan data tabel 2 dapat diketahui sikap belajar siswa berdasarkan hasil observasi dari prasiklus sampai siklus III mengalami peningkatan. Observasi sikap belajar siswa pada prasiklus mendapatkan nilai rata-rata 46,83 pada rentang nilai 0-59 dengan kategori kurang. Pada siklus I mendapatkan nilai rata-rata 68,5 pada rentang nilai 60-74 dengan kategori cukup baik. Pada siklus II mendapatkan nilai rata-rata 78,67 pada rentang nilai 78,67 pada rentang nilai 75-84 dengan kategori baik dan pada siklus III mendapatkan nilai rata-rata 85,83 pada rentang nilai 85-100 dengan kategori sangat baik. Berdasarkan tabel tersebut dapat disimpulkan bahwa peningkatan sikap belajar siswa berdasarkan hasil observasi prasiklus sampai siklus III mengalami peningkatan dengan kategori sangat baik. Perbandingan hasil observasi sikap belajar siswa dari prasiklus sampai siklus III juga dapat dilihat pada grafik berikut.

\section{Grafik 1 Perbandingan Hasil Observasi Sikap Belajar Siswa}

Prasiklus, Siklus I, Siklus II, dan Siklus III

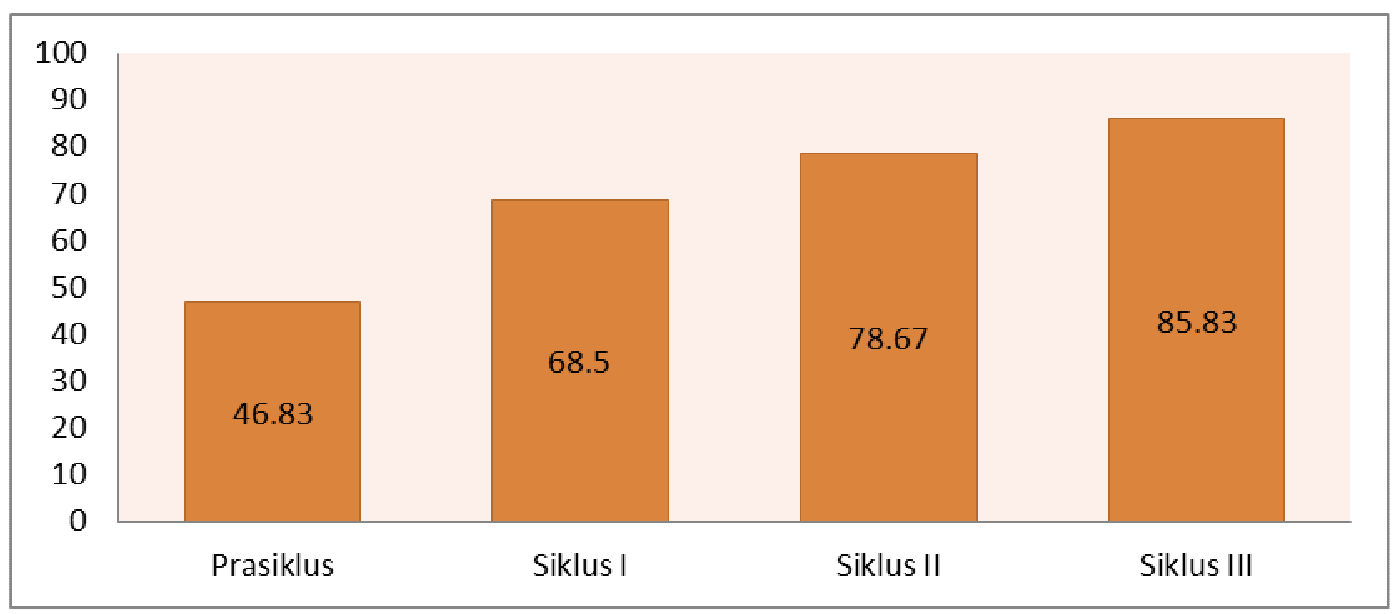

Berdasarkan grafik 1 dapat dilihat bahwa sikap belajar siswa berdasarkan hasil observasi dari prasiklus sampai siklus III mengalami peningkatan. Pada prasiklus sikap belajar siswa mendapatkan nilai rata-rata 46,83 dengan kategori kurang. Pada siklus I mendapatkan nilai rata-rata 68,5 dengan kategori cukup baik. Pada siklus II mendapatkan nilai rata-rata 78,67 dengan kategori baik dan pada siklus III mendapatkan nilai rata-rata 85,83 dengan kategori sangat baik. Hal tersebut membuktikan bahwa dengan adanya model pembelajaran Think Pair Share dan media video dakwah bermuatan pendidikan karakter dapat meningkatkan sikap belajar siswa.

\section{Peningkatan Sikap Belajar Siswa Berdasarkan Hasil Angket}

Angket sikap belajar siswa digunakan peneliti untuk menilai peningkatan sikap belajar siswa saat proses pembelajaran berlangsung dari prasiklus sampai siklus III. 
Perbandingan dari hasil angket setelah dilakukan pembelajaran dari prasiklus sampai siklus III dapat dilihat pada tabel berikut.

Tabel 3 Perbandingan Hasil Angket Sikap Belajar Siswa

Prasiklus, Siklus I, Siklus II, dan Siklus III

\begin{tabular}{|c|c|c|c|c|c|c|c|c|c|}
\hline \multirow{2}{*}{ No } & $\begin{array}{c}\text { Rentang } \\
\text { nilai }\end{array}$ & \multicolumn{2}{|c|}{ Prasiklus } & \multicolumn{2}{c|}{ Siklus I } & \multicolumn{2}{c|}{ Siklus II } & \multicolumn{2}{c|}{ Siklus III } \\
\cline { 3 - 10 } & F & \% & F & \% & F & \% & F & $\%$ \\
\hline 1 & $85-100$ & 0 & 0 & 0 & 0 & 0 & 0 & 0 & 0 \\
\hline 2 & $75-84$ & 0 & 0 & 4 & 13,33 & 11 & 36,67 & 16 & 53,33 \\
\hline 3 & $60-74$ & 8 & 26,67 & 11 & 36,67 & 18 & 60 & 14 & 46,67 \\
\hline 4 & $0-59$ & 22 & 73,33 & 15 & 50 & 1 & 3,33 & 0 & 0 \\
\hline \multicolumn{2}{|c|}{ Jumlah } & 30 & 100 & 30 & 100 & 30 & 100 & 30 & 100 \\
\hline \multicolumn{2}{|c|}{ Rata-rata } & \multicolumn{2}{|c|}{55,13} & \multicolumn{2}{|c|}{61,67} & 70,87 & \multicolumn{2}{c|}{75,4} \\
\hline
\end{tabular}

Berdasarkan tabel 3 dapat diketahui peningkatan sikap belajar siswa berdasarkan hasil angket dari prasiklus sampai siklus III mengalami peningkatan. Angket sikap belajar siswa pada prasiklus mendapatkan nilai rata-rata 55,13 pada rentang nilai 0-59 dengan kategori kurang. Pada siklus I mendapatkan nilai rata-rata 61,67 pada rentang nilai 60-74 dengan kategori cukup baik. Pada siklus II mendapatkan nilai rata-rata 70,87 pada rentang nilai 60-74 dengan kategori cukup baik dan pada siklus III angket sikap belajar siswa mendapatkan nilai rata-rata 75,4 pada rentang nilai 75-84 dengan kategori baik. Berdasarkan tabel tersebut dapat disimpulkan bahwa peningkatan sikap belajar siswa berdasarkan angket prasiklus sampai siklus III mengalami peningkatan dengan kategori baik. Perbandingan hasil angket sikap belajar siswa dari prasiklus sampaisiklus III dapat dilihat pada grafik berikut.

\section{Grafik 2 Perbandingan Hasil Angket Sikap Belajar Siswa}

Prasiklus, Siklus I, Siklus II, dan Siklus III

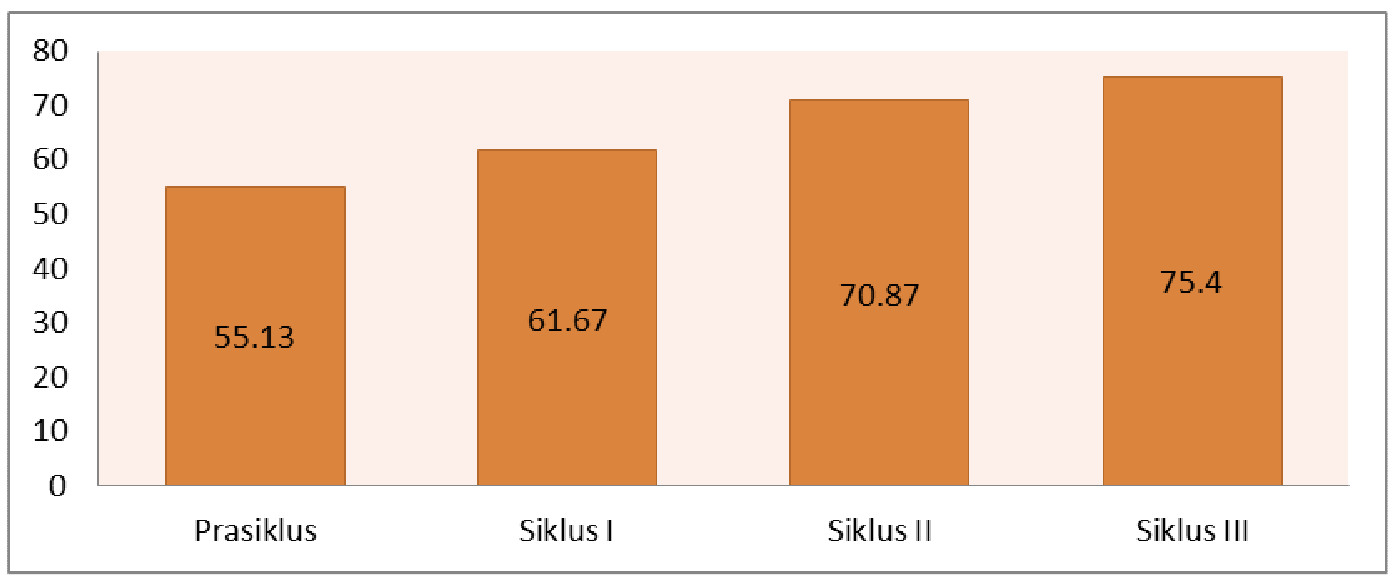


Berdasarkan grafik 2 dapat diketahui bahwa sikap belajar siswa berdasarkan hasil angket dari prasiklus sampai siklus III mengalami peningkatan. Pada prasiklus sikap belajar siswa mendapatkan nilai rata-rata 55,13. Pada siklus I mendapatkan nilai rata-rata 61,67. Pada siklus II mendapatkan nilai rata-rata 70,87 dan pada siklus III mendapatkan nilai ratarata 75,4 . Hal tersebut membuktikan bahwa dengan adanya model pembelajaran Think Pair Share dan media video dakwah bermuatan pendidikan karakter, berdasarkan angket prasiklus sampai siklus III nilai sikap belajar siswa menjadi meningkat yaitu pada kategori baik.

\section{Wawancara}

Dari hasil wawancara sikap belajar siswa yang telah dilakukan pada pembelajaran prasiklus, siklus I, siklus II, dan siklus III dapat diketahui adanya perubahan sikap siswa ke arah yang lebih positif dalam proses pembelajaran menulis paragraf persuasif. Data wawancara tersebut diambil dari seluruh siswa kelas X MA Al Anwar. Hal ini bertujuan untuk mengetahui sikap siswa terhadap pembelajaran menulis paragraf persuasif dengan model think pair share dan media video dakwah bermuatan pendidikan karakter.

Wawancara sikap belajar siswa pada pembelajaran prasiklus terdiri atas 5 aspek pertanyaan, yaitu 1) apakah kamu membaca doa sebelum pembelajaran dimulai, 2) apakah kamu tepat waktu ketika masuk kelas, 3) apakah kamu memperhatikan guru ketika menjelaskan materi pelajaran, 4) apakah kamu mengikuti pembelajaran di kelas dengan sungguh-sungguh, 5) apakah kamu mengerjakan tugas dari guru dan mengumpulkannya tepat waktu.

Berdasarkan hasil wawancara yang dilakukan terhadap seluruh siswa kelas X MA Al Anwar dapat diketahui bahwa terdapat 7 siswa atau 23,33\% menjawab "Ya" pada kelima aspek tersebut karena siswa tertarik dengan pembelajaran yang dilakukan. 5 siswa atau 16,67\% menjawab "Tidak" pada kelima aspek, karena siswa tidak tertarik dengan pembelajaran yang telah dilakukan dan 18 siswa atau 60\% ada yang menjawan "Ya" dan ada yang menjawab "Tidak" pada kelima aspek tersebut, karena siswa belum tertarik dengan pembelajaran yang telah dilakukan.

Wawancara pada pembelajaran siklus I juga terdiri atas 5 aspek pertanyaan yaitu, 1) apakah kamu membaca doa sebelum pembelajaran dimulai, 2) apakah kamu memperhatikan guru saat menjelaskan materi pelajaran, 3) apakah kamu memperhatikan video yang ditayangkan oleh guru dengan sungguh-sungguh, 4) apakah kamu bisa bekerja sama dengan temanmu saat berdiskusi kelompok. 
Dari hasil wawancara yang dilakukan terhadap seluruh siswa kelas X MA Al Anwar, masing-masing siswa mempunyai jawaban yang berbeda. Dari 30 siswa terdapat $50 \%$ siswa menjawab "Ya" pada kelima aspek tersebut, karena siswa tertarik dengan dan senang dengan pembelajaran yang telah dilakukan. 13,33\% siswa atau 4 siswa menjawab "Tidak" pada kelima aspek tersebut, karena siswa tidak tertarik dengan pembelajaran yang dilakukan dan 11 siswa atau 36,67\% ada yang menjawab "Ya" dan ada yang menjawab "Tidak" pada kelima aspek tersebut, karena siswa sedikit tertarik dengan pembelajaran yang dilakukan.

Wawancara sikap belajar siswa pada pembelajaran siklus II pertanyaannya sama dengan wawancara pada siklus I, terdiri dari 5 aspek pertanyaan. Pada wawancara sikap siklus II ini hasilnya lebih meningkat, dari 30 siswa terdapat 18 siswa atau $60 \%$ yang menjawab "Ya" pada kelima aspek tersebut, karena siswa senang dan tertarik dengan pembelajaran yang telah dilakukan. 2 siswa atau 6,67\% menjawab "Tidak" pada kelima aspek tersebut, karena siswa tidak tertarik dengan pembelajaran yang dilakukan dan 10 siswa atau 33,33\% ada yang menjawab "Ya" dan ada yang menjawab "Tidak" pada kelima aspek tersebut, karena siswa mulai tertarik dengan pembelajaran yang telah dilakukan sedangkan hasil wawancara sikap belajar siswa pada pembelajaran siklus III lebih meningkat dari siklussiklus sebelumnya. Berdasarkan wawancara yang peneliti lakukan terhadap seluruh siswa kelas X MA Al Anwar, dapat disimpulkan bahwa sebagian besar siswa senang dan tertarik dengan pembelajaran menulis paragraf persuasif dengan model think pair share dan media video dakwah bermuatan pendidikan karakter.

\section{Peningkatan Motivasi Belajar Siswa}

Setelah penelitian dilakukan, peningkatan tidak hanya terjadi pada hasil tes menulis paragraf persuasif saja, melainkan juga terjadi peningkatan motivasi belajar siswa setelah dilakukan pembelajaran dengan model think pair share dan media video dakwah bermuatan pendidikan karakter. Hal ini dapat diketahui dari perbandingan hasil instrumen nontes prasiklus, siklus I, siklus II, dan siklus III, yang meliputi observasi, angket, wawancara dan dokumentasi.

\section{Peningkatan Motivasi Belajar Siswa Berdasarkan Hasil Observasi}

Observasi motivasi belajar siswa digunakan peneliti untuk menilai peningkatan motivasi belajar siswa saat proses pembelajaran berlangsung baik dari prasiklus, siklus I, siklus II, dan siklus III. Perbandingan dari hasil observasi setelah dilakukan pembelajaran dari prasiklus sampai siklus III dapat dilihat pada tabel berikut. 
Tabel 4 Perbandingan Hasil Observasi Motivasi Belajar Siswa

Prasiklus, Siklus I, Siklus II, dan Siklus III

\begin{tabular}{|c|c|c|c|c|c|c|c|c|c|}
\hline \multirow{2}{*}{ No } & \multirow{2}{*}{$\begin{array}{c}\text { Rentang } \\
\text { nilai }\end{array}$} & \multicolumn{2}{|c|}{ Prasiklus } & \multicolumn{2}{|c|}{ Siklus I } & \multicolumn{2}{|c|}{ Siklus II } & \multicolumn{2}{|c|}{ Siklus III } \\
\hline & & $\mathbf{F}$ & $\%$ & $\mathbf{F}$ & $\%$ & $\mathbf{F}$ & $\%$ & $\mathbf{F}$ & $\%$ \\
\hline 1 & $85-100$ & 0 & 0 & 1 & 3,33 & 3 & 10 & 19 & 63,33 \\
\hline 2 & $75-84$ & 0 & 0 & 2 & 6,67 & 12 & 40 & 10 & 33,33 \\
\hline 3 & $60-74$ & 1 & 3,33 & 23 & 76,67 & 15 & 50 & 1 & 3,33 \\
\hline 4 & $0-59$ & 29 & 96,67 & 4 & 13,33 & 0 & 0 & 0 & 0 \\
\hline \multicolumn{2}{|r|}{ Jumlah } & 30 & 100 & 30 & 100 & 30 & 100 & 30 & 100 \\
\hline \multicolumn{2}{|r|}{ Rata-rata } & \multicolumn{2}{|c|}{40,17} & \multicolumn{2}{|c|}{64,67} & \multicolumn{2}{|c|}{73,17} & \multicolumn{2}{|c|}{84,33} \\
\hline
\end{tabular}

Berdasarkan tabel 4 dapat diketahui bahwa motivasi belajar siswa dari hasil observasi prasiklus sampai siklus III mengalami peningkatan. Motivasi belajar siswa pada prasiklus mendapatkan nilai rata-rata 40,17 pada rentang nilai 0-59 dengan kategori kurang. Pada siklus I mendapatkan nilai rata-rata 64,67 pada rentang nilai 60-74 dengan kategori cukup baik. Pada siklus II mendapatkan nilai rata-rata 73,17 pada rentang nilai 60-74 dengan kategori cukup baik dan pada siklus III mendapatkan nilai rata-rata 84,33 pada rentang nilai 75-84 dengan kategori baik. Berdasarkan tabel tersebut dapat disimpulkan bahwa peningkatan motivasi belajar siswa berdasarkan hasil observasi prasiklus sampai siklus III mengalami peningkatan dengan kategori baik. Perbandingan hasil observasi motivasi belajar siswa dari prasiklus sampai siklus III dapat dilihat pada grafik berikut ini.

Grafik 3 Perbandingan Hasil Observasi Motivasi Belajar Siswa

Prasiklus, Siklus I, Siklus II, dan Siklus III

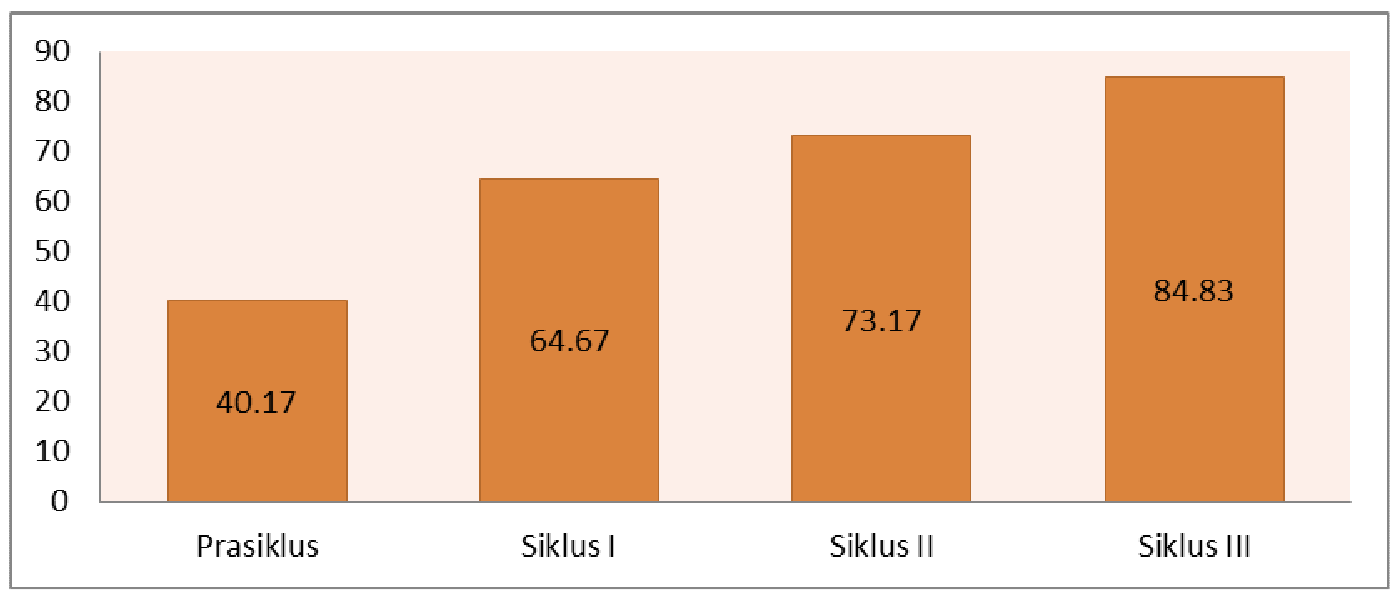


Berdasarkan grafik 4.24 dapat dilihat bahwa motivasi belajar siswa berdasarkan hasil observasi dari prasiklus sampai siklus III mengalami peningkatan. Motivasi belajar siswa pada prasiklus mendapatkan nilai rata-rata 40,17. Pada siklus I mendapatkan nilai rata-rata 64,67. Pada siklus II mendapatkan nilai rata-rata 73,17 dan pada siklus III mendapatkan nilai rata-rata 84,83 . Hal tersebut membuktikan bahwa dengan adanya model pembelajaran Think Pair Share dan media video dakwah bermuatan pendidikan karakter, motivasi belajar siswa dari prasiklus sampai siklus III menjadi meningkat yaitu pada kategori baik.

\section{Peningkatan Motivasi Belajar Siswa Berdasarkan Hasil Angket}

Angket motivasi belajar siswa digunakan peneliti untuk menilai peningkatan motivasi belajar siswa saat proses pembelajaran berlangsung dari prasiklus sampai siklus III. Perbandingan dari hasil angket setelah dilakukan pembelajaran dari prasiklus sampai siklus III dapat dilihat pada tabel berikut.

Tabel 5 Perbandingan Hasil Angket Motivasi Belajar Siswa

Prasiklus, Siklus I, Siklus II, dan Siklus III

\begin{tabular}{|c|c|c|c|c|c|c|c|c|c|}
\hline \multirow{2}{*}{ No } & Rentang & \multicolumn{2}{|c|}{ Prasiklus } & \multicolumn{2}{c|}{ Siklus I } & \multicolumn{2}{c|}{ Siklus II } & \multicolumn{2}{c|}{ Siklus III } \\
\cline { 3 - 10 } & nilai & F & \% & F & \% & F & \% & F & $\%$ \\
\hline 1 & $85-100$ & 0 & 0 & 0 & 0 & 6 & 20 & 8 & 26,67 \\
\hline 2 & $75-84$ & 1 & 3,33 & 5 & 16,67 & 13 & 43,33 & 16 & 53,33 \\
\hline 3 & $60-74$ & 27 & 90 & 25 & 83,33 & 10 & 33,3 & 6 & 20 \\
\hline 4 & $0-59$ & 2 & 6,67 & 0 & 0 & 1 & 3,33 & 0 & 0 \\
\hline \multicolumn{2}{|c|}{ Jumlah } & 30 & 100 & 30 & 100 & 30 & 100 & 30 & 100 \\
\hline \multicolumn{2}{|c|}{67,73} & \multicolumn{2}{|c|}{70,67} & \multicolumn{2}{|c|}{77,6} & \multicolumn{2}{c|}{80,27} \\
\hline
\end{tabular}

Berdasarkan tabel 5 dapat diketahui bahwa motivasi belajar siswa berdasarkan hasil angket dari prasiklus sampai siklus III mengalami peningkatan. Angket motivasi belajar siswa prasiklus mendapatkan nilai rata-rata 67,73 pada rentang nilai 60-74 dengan kategori cukup baik. Pada siklus I mendapatkan nilai rata-rata 70,67 pada rentang nilai 60-74 dengan kategori cukup baik. Pada siklus II mendapatkan nilai rata-rata 77,6 pada rentang nilai 75-84 dengan kategori baik dan pada siklus III angket motivasi belajar siswa mendapatkan nilai rata-rata 80,27 pada rentang nilai 75-84 dengan kategori baik. Berdasarkan tabel tersebut dapat disimpulkan bahwa peningkatan motivasi belajar siswa berdasarkan angket prasiklus 
sampai siklus III mengalami peningkatan dengan kategori baik. Perbandingan hasil angket motivasi belajar siswa dari prasiklus sampai siklus III juga dapat dilihat pada grafik berikut.

\section{Grafik 4 Perbandingan Hasil Angket Motivasi Belajar Siswa}

Prasiklus, Siklus I, Siklus II, dan Siklus III

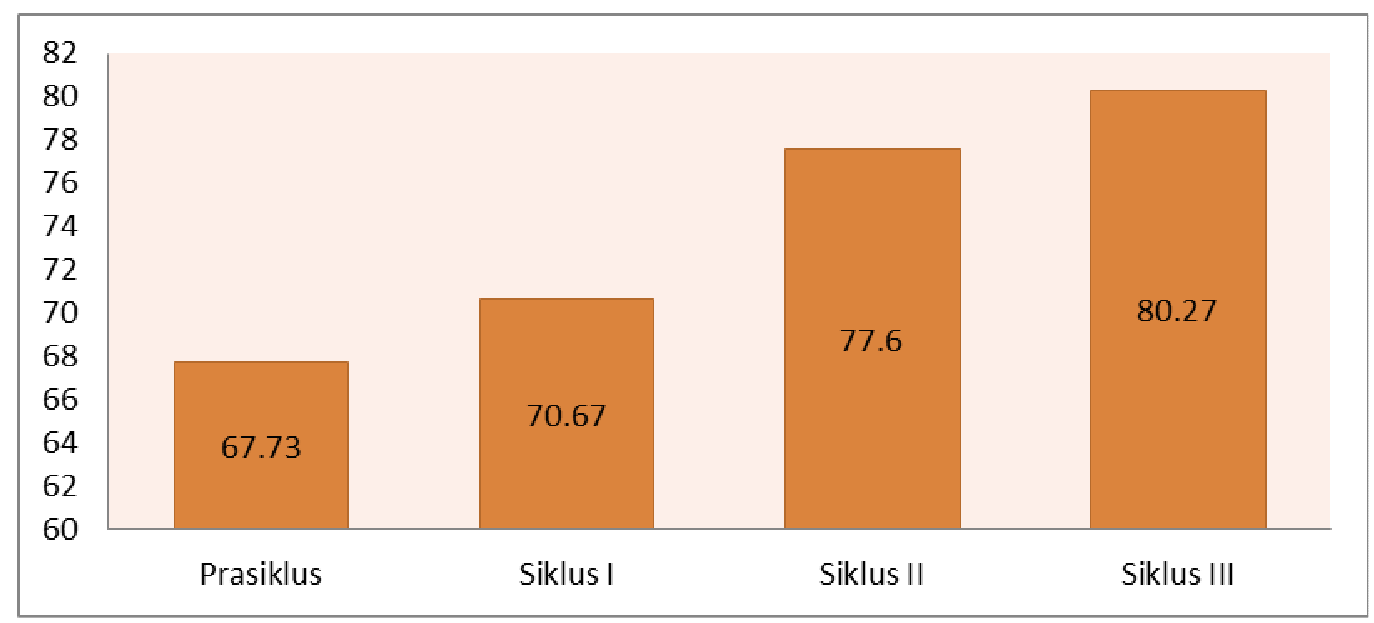

Berdasarkan grafik 4.25 dapat diketahui bahwa motivasi belajar siswa berdasarkan hasil angket dari prasiklus sampai siklus III mengalami peningkatan. Pada prasiklus motivasi belajar siswa mendapatkan nilai rata-rata 67,73. Pada siklus I mendapatkan nilai rata-rata 70,67. Pada siklus II mendapatkan nilai rata-rata 77,6 dan pada siklus III mendapatkan nilai rata-rata 80,27 . Hal tersebut membuktikan bahwa dengan adanya model pembelajaran Think Pair Share dan media video dakwah bermuatan pendidikan karakter, berdasarkan angket prasiklus sampai siklus III nilai motivasi belajar siswa menjadi meningkat yaitu pada kategori baik.

\section{Wawancara}

Dari hasil wawancara motivasi belajar siswa yang telah dilakukan pada pembelajaran prasiklus, siklus I, siklus II, dan siklus III dapat diketahui adanya perubahan motivasi siswa ke arah yang lebih positif dalamproses pembelajaran menulis paragraf persuasif. Data wawancara tersebut diambil dari seluruh siswa kelas X MA Al Anwar. Hal ini bertujuan untuk mengetahui motivasi siswa terhadap pembelajaran menulis paragraf persuasif dengan model think pair share dan media video dakwah bermuatan pendidikan karakter.

Wawancara motivasi belajar siswa pada pembelajaran prasiklus terdiri atas 5 aspek pertanyaan, yaitu 1) apakah siswa tertarik dengan pembelajaran menulis, 2) apakah pembelajaran menulis merupakan kegiatan yang sulist menurut siswa, 3) apakah kamu mengikuti kegiatan pembelajaran menulis paragraf persuasif dengan sungguh-sungguh, 4) 
apakah kamu menyelesaikan tugas dalam pembelajaran menulis paragraf persuasif, 5) apakah kemampuan menulismu meningkat setelah pembelajaran berlangsung.

Berdasarkan hasil wawancara yang telah peneliti lakukan terhadap siswa kelas X MA Al Anwar pada prasiklus, secara keseluruhan dapat disimpulkan bahwa motivasi siswa dalam pembelajaran menulis paragraf persuasif masih sangat kurang, hal ini terlihat dari sedikitnya siswa yang menjawan "Ya" pada kelima aspek tersebut, hanya ada satu siswa yang menjawab "Ya" pada kelima aspek tersebut dan yang 29 siswa ada yang menjawab "Ya" dan ada yang menjawab "Tidak" pada kelima aspek tersebut. Oleh karena itu sebagian besar siswa tidak tertarik dengan pembelajaran prasiklus.

Wawancara pada pembelajaran siklus I juga terdiri atas 5 aspek pertanyaan, yaitu 1) apakah siswa tertarik dengan pembelajaran menulis paragraf persuasif, 2) apakah siswa memahami penjelasan guru dalam pembelajaran menulis paragraf persuasif, 3) apakah siswa tertarik dengan penerapan model think pair share dan media video dakwah, 4) bagaimana pendapat siswa terhadap model dan media yang digunakan dalam pembelajaran menulis paragraf persuasif, 5) kesulitan apa yang dihadapi selama kegiatan pembelajaran menulis paragraf persuasif berlangsung.

Berdasarkan hasil wawancara yang dilakukan terhadap siswa kelas X MA Al Anwar pada siklus I dapat disimpulkan bahwa siswa senang dan tertarik dengan pembelajaran yang telah dilakukan. Dari 30 siswa 17 siswa merasa senang dan tertarik dengan pembelajaran tersebut, 3 siswa merasa tidak tertarik dengan pembelajaran tersebut dan 12 siswa merasa sedikit tertarik dengan pembelajaran yang dilakukan.

Wawancara motivasi belajar siswa pada pembelajaran siklus II memiliki pertanyaan yang sama dengan wawancara pada siklus I, yaitu terdiri atas 5 aspek pertanyaan. Pada wawancara motivasi siswa pada siklus II ini hasilnya lebih meningkat, dari 30 siswa yang mengikuti wawancara $60 \%$ siswa merasa senang dan tertarik dengan pembelajaran yang telah dilakukan dan $40 \%$ siswa mulai tertarik dengan pembelajaran yang dilakukan, sedangkan hasil wawancara motivasi belajar siswa pada pembelajaran siklus III lebih meningkat dari siklus-siklus sebelumnya. Berdasarkan wawancara yang peneliti lakukan terhadap seluruh siswa kelas X MA Al Anwar, dapat disimpulkan bahwa secara keseluruhan siswa senang dan tertarik dengan pembelajaran menulis paragraf persuasif yang telah dilakukan.

\section{PENUTUP}

Berdasarkan hasil penelitian dan pembahasan dalam penelitian tindakan kelas ini dapat disimpulkan sebagai berikut. 
1. Keterampilan menulis paragraf persuasif siswa kelas X MA Al Anwar Mranggen Demak setelah mengikuti pembelajaran menulis paragraf persuasif dengan menggunakan model Think Pair Share dan media video dakwah bermuatan pendidikan karakter mengalami peningkatan. Hal tersebut dapat terlihat dari perubahan nilai rata-rata kelas yang dicapai siswa pada prasiklus, siklus I, siklus II, dan siklus III. Pada prasiklus siswa mendapatkan nilai rata-rata kelas 43,5. Pada siklus I nilai rata-rata kelas siswa meningkat menjadi 61,17. Dari prasiklus ke siklus I nilai siswa mengalami peningkatan dengan selisih nilai 17,67. Pada pembelajaran siklus II siswa mendapatkan nilai rata-rata kelas sebesar 64,83 dan pada siklus III nilai rata-rata kelas siswa meningkat menjadi 78. Dari pembelajaran siklus I ke siklus II meningkat dengan selisih nilai 3,66 sedangkan antara siklus II ke siklus III meningkat dengan selisih nilai 13,17. Hal tersebut membuktikan bahwa hasil menulis paragraf persuasif siswa mengalami peningkatan dari prasiklus, siklus I, siklus II, dan siklus III dengan kategori baik.

2. Analisis data nontes melalui observasi, angket, wawancara, dan dokumentasi menunjukkan bahwa terjadi peningkatan sikap belajar siswa selama pembelajaran prasiklus, siklus I, siklus II, dan siklus III dengan model think pair share dan media video dakwah bermuatan pendidikan karakter.Hal tersebut dapat terlihat dari hasil data nontes siswa yang telah dilakukan. Pada angket sikap tahap prasiklus diperoleh rata-rata 55,13. Pada siklus I diperoleh rata-rata 61,67, siklus II diperoleh rata-rata 70,87 dan siklus II diperoleh rata-rata 75,4. Dari observasi prasiklus diperoleh rata-rata 46,83, pada siklus I diperoleh rata-rata 68,5, pada siklus II diperoleh rata-rata 78,67 dan pada siklus III diperoleh rata-rata 85,83 .

3. Berdasarkan hasil penelitian, dapat diketahui bahwa terjadi peningkatan motivasi belajar siswa selama mengikuti kegiatan pembelajaran menulis paragraf persuasif dengan model think pair share dan media video dakwah bermuatan pendidikan karakter. Hal ini dapat terlihat dari hasil data nontes yang telah dilakukan, yaitu melalui observasi, angket, wawancara dan dokumentasi pada prasiklus, siklus I, siklus II, dan siklus III. Hasil angket motivasi prasiklus diperoleh rata-rata 67,73. Pada siklus I diperoleh rata-rata 70,67, pada siklus II diperoleh rata-rata 77,6 dan pada siklus III diperoleh rata-rata 80,27. Sedangkan dari data nontes hasil observasi motivasi siswa pada prasiklus diperoleh rata-rata 40,17. Pada siklus I diperoleh rata-rata 64,67, pada siklus II diperoleh rata-rata 73,17 dan pada siklus III diperoleh rata-rata 84,33 . 


\section{DAFTAR PUSTAKA}

Kesuma, Dharma. et al. (2013). Pendidikan Karakter Kajian Teori dan Praktik di Sekolah. Bandung: PT Remaja Rosdakarya.

Kokasih. (2012). Dasar-Dasar Keterampilan Menulis. Bandung: Yrama Widya.

Rovimiyanti. (2009). Kemampuan Menulis Paragraf Siswa Kelas X SMK Taruna Bhakti Malang Tahun Ajaran 2008/2009”. Jurnal Artikulasi. 8 (2).

Sugiyono. (2015). Metode Penelitian Pendidikan (Pendekatan Kuantitatif, Kualitatif, dan $R \& D)$. Bandung: Alfabeta.

Widoyoko, Eko Putro. (2016a). Evaluasi Program Pembelajaran. Yogyakarta: Pustaka Pelajar.

Widoyoko, Eko Putro. (2016b). Teknik Penyusunan Instrumen Penelitian. Yogyakarta: Pustaka Pelajar. 